\title{
Associations between blood pressure and economic modernization among adults on Rarotonga, the Cook Islands
}

\author{
Stanley J. Ulijaszek, ${ }^{1}$ Stawomir Koziet ${ }^{2}$ \\ ${ }^{1}$ Institute of Social and Cultural Anthropology, University of Oxford, 51 Ban- \\ bury Rd., Oxford, OX2 6PF, UK; E-mail: stanley.ulijaszek@anthro.ox.ac.uk \\ ${ }^{2}$ Institute of Anthropology, Polish Academy of Sciences, Kuźnicza 35, \\ 50-951 Wrocław, Poland
}

\begin{abstract}
Populations in the Pacific islands undergoing economic modernization have experienced a steady rise in the prevalence of hypertension across the second part of the twentieth century. In this analysis, a comparison is made between blood pressure of the Rarotonga, Cook Islands, population in 1996 with values obtained for this population in 1964. In addition, the extent to which education and occupation, as markers of modernization, associate with blood pressure and island of origin is examined, taking into account the use of anti-hypertensive drugs by a subset of the sample. For the males, mean blood pressure shows no difference between 1964 and 1996; for the females, the characteristic increase in blood pressure across the age groups is not statistically significant in the 1996 study population. This might be due to the much more extensive use of anti-hypertension medication in the 1996 sample. Island of origin is a significant predictor of blood pressure irrespective of occupation, use of anti-hypertension medication, age and body mass index. Females born on Rarotonga had higher systolic blood pressure, which was also associated with education level, than those born on other Cook Islands. Males born on Rarotonga had significantly higher diastolic blood pressure than males born elsewhere in the Cook Islands.
\end{abstract}

KEY WORDS blood pressure, modernization, economic status, BMI, Pacific Islands

Prz. Antropol.-Anthropol. Rev. (2003), vol. 66, pp. 65-75, Figs. 4, Tables 3. ISBN 8386969-92-X, ISSN 0033-2003

\section{Introduction}

Populations undergoing economic modernization have experienced a steady rise in the prevalence of hyper- tension and the chronic diseases associated with it [BEAGLEHOLE 1992, POPKIN et al. 1995, KHAN et al. 1993, MCGARVEY et al. 1989]. The factors accompanying modernization found to 
be associated with increased blood pressure include dietary change, increased body weight and fatness, decreased physical activity levels, and psychosocial stress [SCHALL 1995]. In the Pacific Region, hypertension prevalence has been associated with migration among Manus migrants to towns in Papua New Guinea [SCHALL 1991] and Tokelau islanders migrant to New Zealand [BEAGLEHOLE et al. 1977]. Furthermore, Samoans in California and Hawaii have been shown to have greater prevalences of hypertension than Samoans in Western Samoa [MCGARVEY and SCHENDEL 1986]. In the Cook Islands, studies in 1964 and 1953 showed adults living on the remote island of Pukapuka to have low mean blood pressure [MURPHY 1955, PRIOR et al. 1968], while adults on the modernizing island of Rarotonga showed an increase in blood pressure with age, and were taller and heavier, with higher blood pressure, than subjects on Pukapuka [PRIOR et al. 1968]. Among Cook Islanders, blood pressure increases with age for both males and females, women showing a steeper increase in systolic blood pressure than males [PRIOR et al 1968]. SCHALL [1995], in a meta-analysis of 20 traditional and modernizing Pacific populations, confirmed this effect as a general phenomenon. The effects of economic modernization have been largely attributed to commonly measured risk factors including dietary change associated with increased penetration of the world food system, and reduced physical activity associated with increased mechanization of life. However, these account imperfectly for the observed within-population variation observed [CREWS and LOSH 1994]. Furthermore, women score lower than men in most indices of modernization in the Pacific, and blood pressure among modernizing women correlates less well with these indices than among modernizing men [LABARTHE et al. 1973, PATRICK et al. 1983]. These relationships are further complicated by the use of anti-hypertensive drugs among subjects with very high blood pressure. In this analysis, a comparison is made between blood pressure of the Rarotonga population in 1996 with the values obtained for this population by PRIOR et al. [1968] in 1964, and the extent to which education and occupation, as markers of modernization, associate with blood pressure (taking into account the use of anti-hypertensive drugs by a subset of the sample) and island of origin is examined.

\section{Methods}

The 1964 sample comprised of 455 Cook Islander volunteers aged 20 to 82 years, living in Avarua, the urban center of Rarotonga. Blood pressure was measured using a sphygomanometer with the subject seated, at the fourth phase of Korotkoff sounds. The age distribution of this sample was similar to that of the general adult population of Rarotonga [PRIOR et al. 1968]. The 1996 sample comprised of 425 Cook Islanders aged 22 to 86 years, who were recruited by means of a radio and television campaign, on Rarotonga, the Cook Islands, forming a volunteer sample of the total adult population. Older adults were over-represented, while younger adults were under-represented in the 
sample. Ethical permission was obtained from the Ministry of Health, Government of the Cook Islands, prior to undertaking the investigation. Subjects who agreed to take part in the survey were seen at six different clinic sites representative of the demographic and socio-economic distributions of the adult Rarotongan population. Systolic (SBP) and diastolic (DBP) blood pressures were measured in a lying position after 15 minutes rest, using a sphygmomanometer. The fourth phase of Korotkoff sounds was recorded. The data used here is the average of two readings taken one minute apart.

The choice of variables for this study was made in consultation with the Government Anthropologist, an employee of the Cook Islands Civil Service, who suggested that a small number of questions relating to occupation, education, and island of birth would be much more acceptable to both subjects and the Government of the Cook Islands than a longer list. The main economic occupation of individuals was determined by questionnaire. Subjects were questioned by the author with respect to their current occupational status to minimize the possibility of ambiguity of past and present occupations and occupation categories. Prior to analysis, different types of occupation were combined into categories of occupation as follows: traditional subsistence; unemployed (males); housewife (females); manual worker; clerical worker; administrator; and professional. The category of 'traditional subsistence' was merged with that of 'unemployed' for the males, and with the category 'housewife' for the females. The categories 'clerical worker' and 'administrator' were also merged with each other. These mergers were made to allow adequate sample sizes for subsequent analyses.

Height and weight were measured using standard techniques that did not differ across the two surveys, as the protocol used in the 1964 survey was the same as that incorporated in the human biology guide to field methods [Ciba Foundation 1963; WEINER and LOURIE 1969, 1981]. Weight was measured using a beam balance to the nearest pound in the 1964 survey, and with battery-operated Soehnle digital scales to the nearest $100 \mathrm{~g}$ in the 1996 survey. In both surveys, subjects wore the minimum clothing that was considered culturally decent. In the 1996 survey, height was measured using a Harpenden anthropometer to the nearest millimeter. All measurements were made by the first author (SJU), whose intra-observer measurement error was determined by the remeasurement of 15 subjects at the beginning of the study. Values for technical error of measurement (TEM), relative TEM (\%TEM) and coefficient of reliability $(\mathrm{R})$ were determined using formulae given in ULIJASZEK and KERR [1999]. Measurement error values were 0.1 (TEM), 0.11 (\%TEM) and 0.99 (R) respectively, for weight, and 0.3 (TEM), 0.18 (\%TEM) and 0.99 (R) respectively, for height. Values for $\mathrm{R}$ indicate that measurement error was low [ULIJASZEK and LOURIE 1994] for these measures. Unfortunately, there was no report of anthropometric measurement error for the 1964 data. The BMI was calculated by dividing weight (in kilograms) by height (in meters) squared. 
Mean values for SBP and DBP were calculated by age group and sex using SPSS-PC for Windows. Relationships between the blood pressure variables and place of origin, allowing for age and relative weight (BMI) as confounding factors were examined using one way analysis of covariance [KERR et al. 1998]. This gave values for blood pressure adjusted for BMI. The generalized linear model (GLM), using logit-link function where appropriate, was used to test associations between place of origin and socio-economic factors (education and occupation), age, BMI, and the blood pressure variables SBP and DBP. The GLM model allowed analysis of the net effect of the place of origin on individual variables included in the model, and neutralized the effect of having subjects who were using antihypertension medication included in the sample.

\section{Results}

Figures 1 and 2 show mean blood pressures on Rarotonga in 1964 and 1996. For the males, no difference was found between the mean blood pressure of the four age groups in both the 1964 and the 1996 studies (Fig. 1). In the case of the females, however, the characteristic increase in blood pressure across the age groups in the 1964 study population was not found to be as marked for the 1996 study population (Fig. 2). Mean systolic blood pressures for males of the 1964 survey were 131.4 (25-34 years), 138.4 (35-44 years), 143.7 (4554 years), and 149.1 (55-65 years). For females the values were 124.5 (25-34 years), 143.9 (35-44 years), 163.9 (45-
54 years), and 173.0 (55-65 years). Mean diastolic blood pressures for males of the 1964 survey were 85.4 (2534 years), 92.2 (35-44 years), 95.5 (4554 years), and 93.9 (55-65 years). For females the values were 82.2 (25-34 years), 92.3 (35-44 years), 101.5 (45-54 years), and 103.7 (55-65 years). These differences cannot be explained by differences in age structure. The 1996 sample has a greater proportion of older people than the 1964 sample, but there is no apparent bias towards an agerelated increase in blood pressure in the 1996 sample, relative to the earlier study. The absence of increase in blood pressure with age among both males and females in 1996 may be because of more extensive use of hypertensive drugs in this population since 1964 .

Table 1 gives descriptive statistics by sex and age group for the 1996 sample. There are no statistically significant differences in blood pressure between males and females. However, the mean blood pressure for the females is significantly greater among older people (aged $40-59$ and $>60$ years) than younger people (aged 20-39 years) (post hoc Bonferonii test; $\mathrm{p}<0.05$ for SBP and DBP), although among subjects above 60 years of age blood pressure is slightly lower than the 40-59 years age group, possibly due to selective mortality. There is no corresponding age effect for the males. These patterns cannot be attributed to differences in the age structure of the 1996 sample, since there are no significant differences in the age distribution by age group (20-39 years, 40-59 years, 60 years and above) of males versus females (chi-square $=4.4, d f=2, p=$ $0.11)$. 


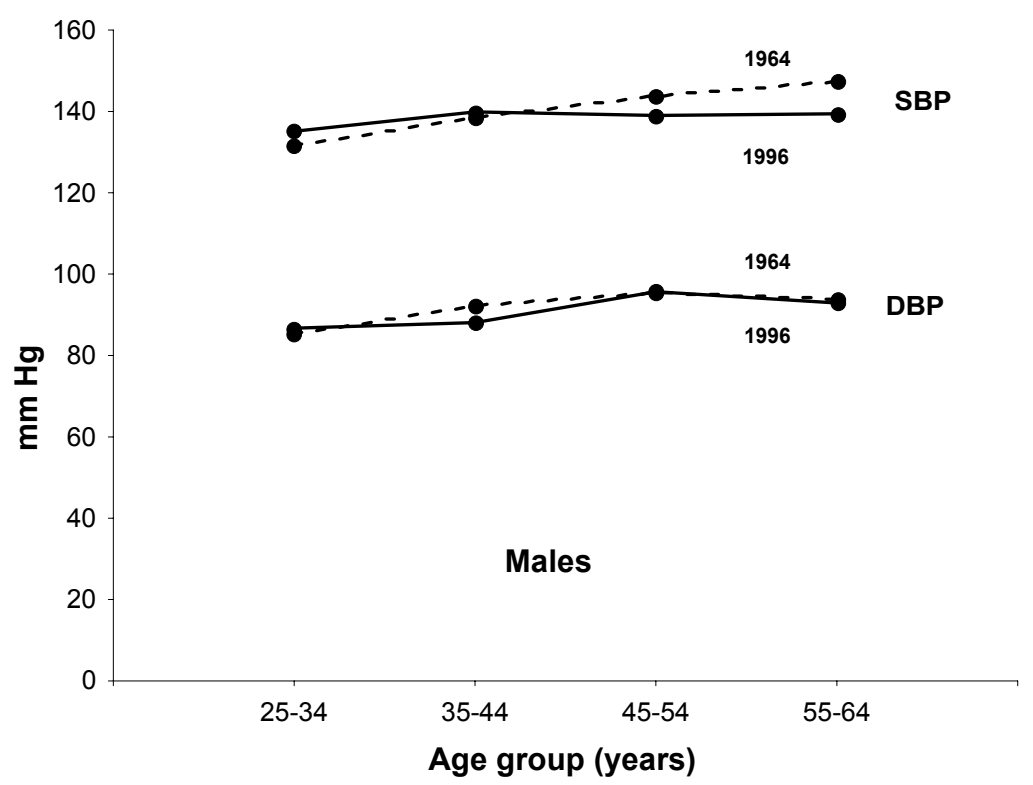

Fig. 1. Mean blood pressure, Rarotonga, 1964 and 1996, males.

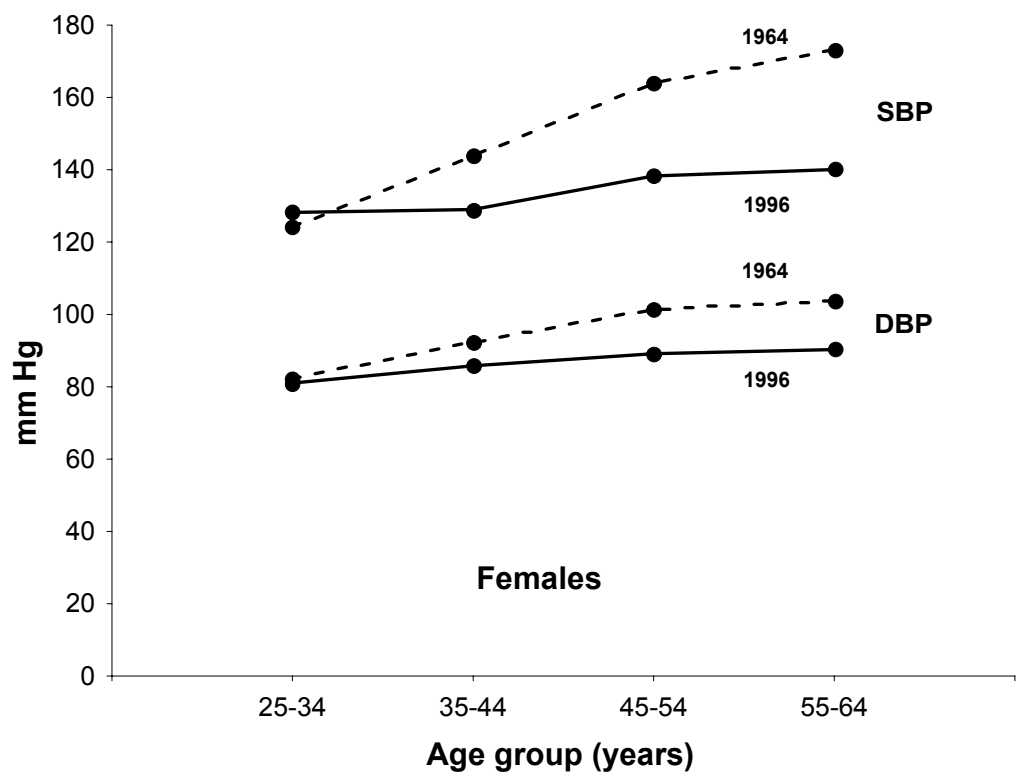

Fig. 2. Mean blood pressure, Rarotonga, 1964 and 1996, females. 
Table 1. Descriptive statistics of blood pressure by age group and sex. Differences between sex and age groups were tested by means of two-way ANOVA

\begin{tabular}{|c|c|c|c|c|c|c|}
\hline \multirow[b]{2}{*}{ Age group } & \multicolumn{3}{|c|}{ Males } & \multicolumn{3}{|c|}{ Females } \\
\hline & $\mathrm{N}$ & Mean & $\mathrm{SD}$ & $\mathrm{N}$ & Mean & $\mathrm{SD}$ \\
\hline & \multicolumn{6}{|c|}{$\mathrm{SBP}[\mathrm{mmHg}]$} \\
\hline $20-39$ & 15 & 135.1 & 14.3 & 45 & 127.2 & 19.5 \\
\hline $40-59$ & 67 & 139.6 & 15.9 & 133 & 139.4 & 18.7 \\
\hline 60 and more & 65 & 139.4 & 20.6 & 99 & 138.3 & 18.2 \\
\hline Sex & $\mathrm{F}=1.82$ & & & & & \\
\hline Age & $\mathrm{F}=3.84^{*}$ & & & & & \\
\hline \multirow[t]{2}{*}{ Interaction } & $F=0.79$ & & & & & \\
\hline & \multicolumn{6}{|c|}{ DBP $[\mathrm{mmHg}]$} \\
\hline $20-39$ & 15 & 86.0 & 16.3 & 45 & 81.2 & 13.5 \\
\hline $40-59$ & 67 & 91.6 & 13.9 & 133 & 90.1 & 13.7 \\
\hline 60 and more & 65 & 90.0 & 12.7 & 99 & 89.4 & 14.2 \\
\hline Sex & $\mathrm{F}=1.78$ & & & & & \\
\hline Age & $\mathrm{F}=4.96^{* *}$ & & & & & \\
\hline Interaction & $\mathrm{F}=0.42$ & & & & & \\
\hline
\end{tabular}

Figures 3 and 4 give BMI-adjusted mean blood pressure by age group and sex according to island of birth. Females born on Rarotonga had higher systolic blood pressure than those born on other Cook Islands, while men born on Rarotonga did not. These patterns cannot be attributed to differences in the age structure of the sample, since there are no significant differences in the age distribution according to place of birth
(Rarotonga versus those born elsewhere in the Cook Islands) (chi-square $=0.1$, $d f=2, p=0.94)$. An analysis using the Generalized Linear Model with logit link showed island of birth to be significantly associated with DBP for the males, and with education and SBP for the females (Table 2), but was independent of use of anti-hypertension medication in both sexes (Table 3 ).

Table 2. Relationships between place of birth (in two categories: Rarotonga and elsewhere) and a number of independent variables

\begin{tabular}{lccccc}
\hline \multirow{2}{*}{$\begin{array}{l}\text { Independent } \\
\text { variable }\end{array}$} & \multicolumn{3}{c}{ Males } & & \multicolumn{2}{c}{ Females } \\
\cline { 2 - 3 } \cline { 5 - 6 } & Wald's $\chi^{2}$ & $p$-level & & Wald's $\chi^{2}$ & $p$-level \\
\hline Education & 3.16 & 0.37 & & $\mathbf{9 . 9 6}$ & $\mathbf{0 . 0 2}$ \\
Occupation & 1.94 & 0.58 & & 3.52 & 0.32 \\
Medication & 0.05 & 0.82 & & 0.01 & 0.91 \\
Age & 0.92 & 0.34 & & 0.32 & 0.57 \\
SBP & 1.33 & 0.25 & & $\mathbf{3 . 7 9}$ & $\mathbf{0 . 0 5}$ \\
DBP & $\mathbf{4 . 2 8}$ & $\mathbf{0 . 0 4}$ & & 0.17 & 0.68 \\
BMI & 1.20 & 0.27 & & 0.45 & 0.50 \\
\hline
\end{tabular}




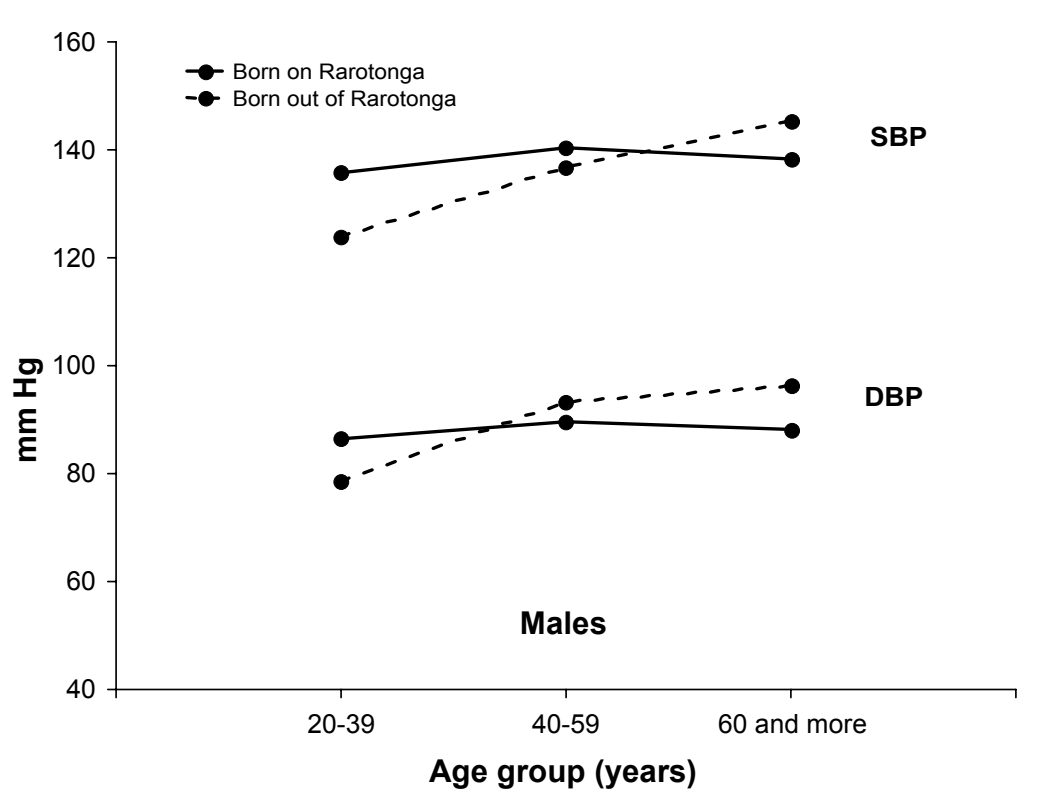

Fig. 3. Mean systolic and diastolic blood pressure according to place of birth, males, Rarotonga 1996.

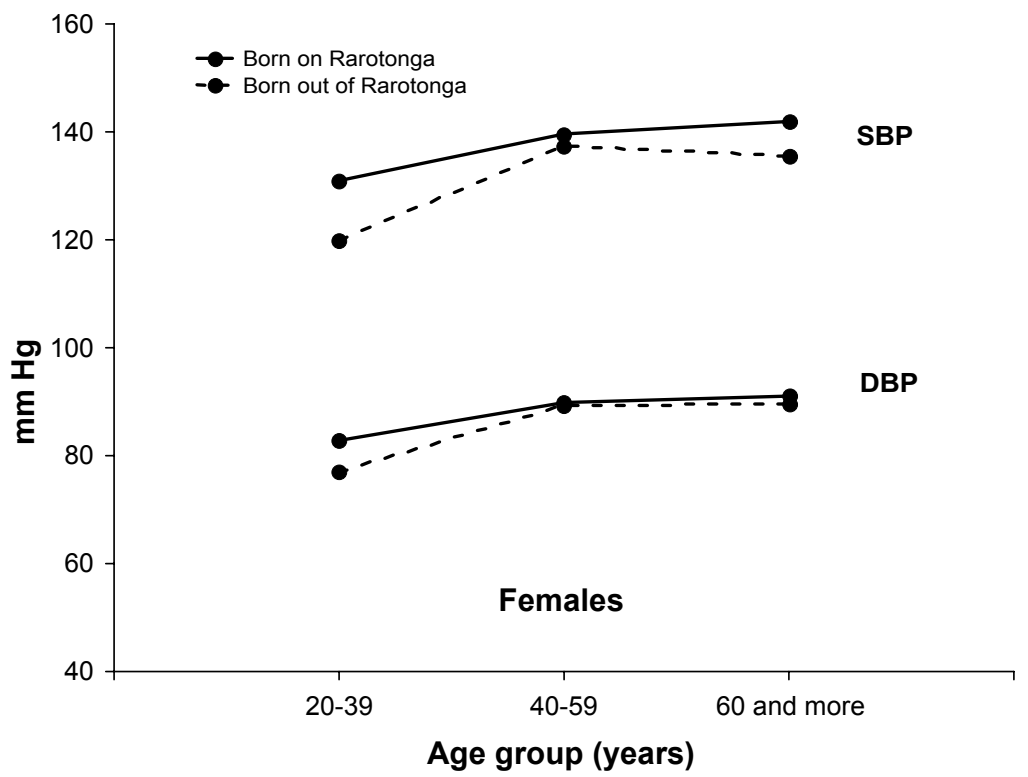

Fig. 4. Mean systolic and diastolic blood pressure according to place of birth, females, Rarotonga 1996. 
Table 3. Relationship between taking hypertension pills (yes/no) and birth place (Rarotonga/elsewhere), education (4 categories), and occupation (4 categories)

\begin{tabular}{lccccc}
\hline & \multicolumn{3}{c}{ Males } & & \multicolumn{2}{c}{ Females } \\
\cline { 2 - 3 } \cline { 5 - 6 } \cline { 5 - 6 } & Chi-square & $p$-level & & Chi-square & $p$-level \\
\hline Birth place & 0.02 & 0.886 & & 0.94 & 0.332 \\
Education & 3.18 & 0.364 & & 7.12 & 0.068 \\
Occupation & 2.95 & 0.399 & & $\mathbf{1 5 . 9 7}$ & $\mathbf{0 . 0 0 1}$ \\
\hline
\end{tabular}

\section{Discussion}

For males on Rarotonga, it appears that blood pressure has shown no further increase above 1964 levels. For the females, blood pressure shows no increase with age for the 1996 sample, although it does for the 1964 sample of PRIOR et al. [1968]. This may be because of much greater medical management of high blood pressure in this population in 1996 compared with 1964. In the 1996 sample, $38 \%$ of females and $29 \%$ of males regularly used anti-hypertension medication. The lower increase in systolic blood pressure with age for males relative to females observed for the Rarotonga population in 1964 by PRIOR et al. [1968], and confirmed as a general phenomenon among modernizing $\mathrm{Pa}$ cific populations by SCHALL [1995], might be a function of differential cardiovascular disease mortality between males and females, whereby males with high blood pressure are more likely to have died at an earlier age. It is generally acknowledged that hypertension is a primary risk factor for mortality due to all-causes and is a good predictor of subsequent coronary heath disease mortality [KANNEL et al. 1967, GOLDBOURT and YAARI 1990].
The age-related pattern of blood pressure change observed in this study may be confounded by the extent to which the use of hypertensive drugs might mask the effects of modernization on blood pressure. Furthermore, the extent of use of hypertensives may be mediated by other modernization variables; in this study, a comparison of subjects taking anti-hypertension drugs according to island of origin, occupation and education, shows there to be no difference for the males, with women with more years of education and higher occupational status taking anti-hypertension medication (Table 3).

Island of origin is a significant predictor of blood pressure in this study, irrespective of occupation, use of antihypertension medication, age and BMI. Island of origin is also associated with level of education for the females, but not for the males. The higher DBP among males born on Islands other than Rarotonga may reflect psychosocial factors associated with modernization effects which are greater on this Island than on any of the other Cook Islands, rather than the duration and extent of exposure to physical factors in the etiology of hypertension. In 1991, the population of Rarotonga was $58 \%$ of the total population of all of the Cook Islands. 
The high population density and concentration of economic resources on this island has resulted in greater economic opportunities at all levels, and a greater proportion of the population engaged in the moneyed economy than any of the other Cook Islands (National Statistical Office [1996]). Furthermore, the dependency ratio (proportion of the population aged less than 15 years and greater than 65 years) is $38 \%$ lower on Rarotonga than on the other islands combined (National Statistical Office [1996]), due largely to declines in fertility rates and resulting in smaller household sizes in which per capita access to resources acquired as a consequence of engagement in the cash economy is greater on Rarotonga than on any of the other islands.

It is also possible that the effects observed may reflect selective migration of Cook Islanders to Rarotonga. Migrants may be more motivated than the populations from whence they came, and may have endocrine characteristics which more easily lead to elevated cortisol levels. In a comparison of premigrants to New Zealand and nonmigrants on the Tokelau Islands, PRIOR et al. [1977] found that younger premigrants had slightly higher systolic and diastolic blood pressures than nonmigrants. These differences may reflect a more acculturated or modernized status of pre-migrants; alternatively, they may reflect essential differences in attitudes and/or personalities between two groups [PRIOR et al. 1977]. If the latter, this might be favorable under the survival conditions of the Pacific Islands before modernization, but unfavorable under current situations of plentiful diet, and access to smoking and alcohol. It is possible that males born elsewhere in the Cook Islands experience greater psychosocial stress than indigenes of Rarotonga. However, there is no evidence that migrants to Rarotonga displace stress by excessive alcohol consumption.

Alternatively, migrants may have been forced to migrate because of the difficult traditional economic conditions of their islands of origin. In this case, the higher DBP of males born elsewhere in the Cook Islands may reflect poor psychosocial adaptation to the stresses of modernization on Rarotonga. One methodological problem obscuring interpretation in the present study is that of separating changes produced by migration from those produced by modernization [LITTLE and BAKER 1988].

It is likely that there are different environmental impacts on blood pressure of males and females respectively. Alcohol consumption and smoking among females is lower than among males, and does not differ according to whether they were born on Rarotonga or elsewhere in the Cook Islands [ULIJASZEK 2002]. Furthermore, selective migration of males and females to Rarotonga might have been influenced by different factors. Given the patriarchal nature of Cook Islands society, female migrants are less likely to have been driven by economic pressures or possibilities than their men, except inasmuch as selective mating might take place for characteristics associated with economic success or failure. The higher SBP of females born on Rarotonga may thus reflect their higher educational level and greater engagement in modern life than those born elsewhere in the Cook Islands. 


\section{Acknowledgements}

We thank Professor Kazumichi Katayama of Kyoto University for his very kind friendship and support of this project, and the Japanese Ministry of Education, Science and Culture, Government of Japan, for financial support. We thank our local counterpart, the late Kauraka Kauraka for his help and friendship, Roro Daniel of the Cook Islands Ministry of Health, and all the people who kindly took part in this survey.

\section{References}

BEAGLEHOLE R., 1992, Blood pressure in the South Pacific: The impact of social change, Ethn. Dis., 2, 55-62

Beaglehole R., C.E. Salmond, A. Hooper, J. Huntsman, J. Stanhope, J.C. Cassel, I.A.M. PRIOR, 1977, Blood pressure and social interaction in Tokelau migrants in New Zealand, J. Chron. Dis., 30, 803-12

Ciba Foundation, 1963, Anthropometry of growth and physique, Human Adaptability Working Party No. 22, London

CRews D.E., S. Losh, 1994, Structural modeling of blood pressure in Samoans, Coll. Antropol., 8, 101-14

Goldbourt U., S. YaARI, 1990, Cholesterol and coronary hearth disease mortality. A 23-year follow-up study of 9902 men in Israel, Arteriosclerosis, 10, 512-19

KanNel W.B., J.E. LeBauer, T.R. DAwBer, P.M. MCNAMARA, 1967, Relation of Body weight to development of coronary hearth disease. The Framingham Study, Circulation, 35, 734-44

Kerr C., R. Taylor, G. Heard, 1998, Handbook of Public Health Methods, McGraw-Hill, Sydney

Khan L.K., G.G. Harrison, O.M. Galal, C. Ritenbaugh, F.M. Shaheen, A. Kerksey, N.M. JEROME, 1993, Prevalence and functional correlates of obesity in an Egyptian village, Ecol. Food Nutr., 34, 311-25
Labarthe D., D. Reed, J. Brody, R. StalLONES, 1973, Health effects of modernization in Palau, Am. J. Epidemiol., 98, 161-174

LitTLE M.A., P.T. BAKER, 1988, Migration and adaptation, [in:] Biological aspects of human migration, C.G.N. Mascie-Taylor and G.W. Lasker (ed.), Cambridge Studies in Biological Anthropology, Cambridge University Press, Cambridge, pp. 167-215

McGarvey S.T., J.R. BINDON, D.E CREws, D.E. SCHENDEL, 1989, Modernization and adiposity: Causes and consequences, [in:] Human Population Biology, M.A. Little and J.D. Haas (ed.), Oxford University Press, New York, pp. 263-79

McGarvey S.T., D.E. Schendel, 1986, Blood pressure of Samoans, [in:] The Changing Samoans, P.T. Baker, J.M. Hanna and T.S. Baker (ed.), Oxford University Press, New York, pp. 350-93

MURPHY W., 1955, Some observations on blood pressure in the humid tropics, NZ. Med. J., 54, 64-73

National Statistical Office, 1996, Cook Islands Annual Statistical Bulletin, Rarotonga: National Statistical Office

PATRICK R.C., I.A.M. Prior, J.C. SMith, A.H. SMITH, 1983, Relationship between blood pressure and modernity among Ponapeans, Int. J. Epidemiol., 12, 36-44

Popkin B.M., S. Paeratakul, K. Ge, Z. FENGYING, 1995, Body weight patterns among the Chinese: results from the 1989 and 1991 China Health and Nutrition Surveys, Am. J. Pub. Health, 85, 690-94

Prior I.A.M., J.G. Evans, H.P.B. Harvey, F. DAVIDSON, M. LindSEY, 1968, Sodium intake and blood pressure in two Polynesian populations, New Engl. J. Med., 279, 515-20

Prior I.A.M., A. HoOPER, J.W. Huntsman, J.M. Stanhope, C.E. SAlmond, 1977, The Tokelau Island migrant study, [in:] Population Structure and Human Variability, G.A. Harrison (ed.), Cambridge University Press, Cambridge, pp. $165-86$

Schall J.I., 1991, Blood Pressure and Lifestyle Change among the Manus of Papua New Guinea: A Migrant Study, Doctoral dissertation, University of Pennsylvania 
SCHALL J.I., 1995, Sex differences in the response of blood pressure to modernization, Am. J. Hum. Biol., 7, 159-72

UliJaszeK S.J., 2002, Modernization and the diet of adults on Rarotonga, the Cook Islands, Ecol. Food Nutr., 41, 203-28

UliJASZeK S.J., D.A. KerR, 1999, Anthropometric measurement error and the assessment of nutritional status, Br. J. Nutr., 82, 165-77

UliJASZEK S.J., J.A. LOURIE, 1994, Intra- and inter-observer error in anthropometric mea- surement, [in:] Anthropometry: The Individual and the Population, S.J. Ulijaszek and C.G.N. Mascie-Taylor (ed.), Cambridge University Press, Cambridge, pp. 30-55

WeINER J.S., J.A. LOURIE, 1969, Human Biology. A Guide to Field Methods, Blackwell Scientific Publications, Oxford

Weiner J.S., J.A. LOURIE, 1981, Practical Human Biology, Academic Press, London

\section{Streszczenie}

Jednym z przejawów ekonomicznych przemian, określanych terminem modernizacji, jakich doświadczyły populacje wysp Pacyfiku w ostatnich kilkudziesięciu latach, jest stały wzrost odsetka osób z nadciśnieniem oraz wzrost zachorowalności na choroby pochodne. Wśród czynników towarzyszących zmianom ekonomicznym i wywierających bezpośredni wpływ na wzrost ciśnienia krwi wymienia się głównie: jakościowe a często ilościowe zmiany diety, wzrost masy i otłuszczenia ciała, spadek poziomu aktywności fizycznej osobników oraz stres psychospołeczny (np. charakterystyczny dla procesów migracyjnych). Celem pracy było porównanie ciśnienia krwi w populacji wyspy Rarotonga (Wyspy Cooka), badanej w latach 1964 i 1996. Na podstawie danych z 1996 r. zbadano dodatkowo zależności pomiędzy miejscem urodzenia (Rarotonga lub inne wyspy) a ciśnieniem krwi, przy kontroli poziomu wykształcenia i charakteru wykonywanej pracy (czyli wskaźników modernizacji), używania leków obniżających ciśnienie oraz wieku i wskaźnika masy ciała (BMI).

U mężczyzn średnia wartość ciśnienia krwi w badanych klasach wieku nie uległa zmianom pomiędzy latami 1964 i 1996 (Rys. 1). U kobiet badanych w 1996 roku charakterystyczny wzrost ciśnienia krwi z wiekiem nie osiagnął poziomu istotnego statystycznie w porównaniu do populacji kobiet badanych 1964 roku (Rys. 2). W populacji z 1996 roku nie wykazano istotnych różnic międzypłciowych $\mathrm{w}$ trzech grupach wiekowych (Tab. 1). Miejsce urodzenia okazało się istotnym niezależnym czynnikiem wpływających na wartości ciśnienia krwi (Tab. 2-3). Kobiety urodzone na Rarotonga odznaczały się wyższymi wartościami skurczowego, natomiast mężczyźni rozkurczowego ciśnienia krwi, przy kontroli pozostałych czynników. U mężczyzn w grupie imigrantów występowała także silniejsza zależność pomiędzy wiekiem a ciśnieniem krwi. Wydaje się, że głównym powodem wzrostu ciśnienia imigrantów były czynniki psychologiczno-społeczne związane z procesami migracyjnymi (Rys. 3-4). 